pull it open. 5. If piles are protruding and inflamed or thrombosed it is often practicable to apply the clamp parallel to the anus, thus bringing the rectum down into apposition with the margin; almost as if a ring had been excised, but always leaving intervals of untouched mucous membrane, so that subsequent wide gaping of the wounds or contraction of the anus is avoided. If the piles are numerous and large $I$ prefer to crush some in a longitudinal, and the alternate ones in a horizontal, direction, so as to prevent the contraction and yet remove efficiently. 6 . The parts are then gently pressed up. Perhaps once in 50 cases it is necessary to touch an oozing spot with the point of a cautery. Twice or thrice in the whole series a spurting arteriole has demanded ligature. A morphia and iodoform suppository is then placed inside and a ball-shaped absorbent pad is pressed against the part. 7. At night in perhaps 10 per cent. of the cases the catheter is required, but almost never subsequently. It is the elderly men who may need it. 8. On the fourth day a dose of castor oil is administered. When the bowels act for the first time it is not unusual for a slight oozing to occur. But we have no record of any case of serious hæmorrhage. About the fifth or sixth day the burnt and crushed pedicle may gape a little and granulations appear. These are visible, and require daily dressing, until about the fourteenth day. Occasionally with straining the wounds gape half an inch wide, and healing may then take three weeks. In 100 cases 85 were allowed to go healed within 15 days. In 8 cases they were kept a week longer, and 7 were detained nearly a month, usually on account of old-standing anæmia and cardiac or pulmonary disease. The age of all the patients was between 20 and 75 . 8 per cent were over 60 years of age. In the after-treatment it is a comfort not to have to search for buried ligatures or stitches, which are bound to become more or less septic.

We have not had a single case of abscess, or hæmatoma, or of hæmorrhage, either operative or post-operative, in this series. In a former series post-operative hrmorrhage was twice experienced -from a different pattern clamp that did not crush effectively and from insufficient cauterisation. And in the former series of 60 cases there was one death from pulmonary embolism in a weakly old man.

As complications of the disease in the present series I note severe anæmia in 5 per cent.; diarrhœea, 3 per cent.; cardiac disease, 2 per cent.; bronchitis, 2 per cent.; syphilitic ulcers and condylomata in 1 case; fistula in 2 cases; and fissure in 3 cases. Anæsthesia (chloroform) gave trouble only in one patient, who required artificial respiration for a minute or two. Spinal analgesia was not employed in any of these cases and local analgesia only in a very few slight ones.

As to after-complications, in 2 cases the catheter was needed for a few days. In 2 cases secondary operations were needed within a few weeks. Two or three operations were done at a later period for recurrence. These results are the more noteworthy that quite a quarter of the operations must have been performed by junior surgeons of little experience, but after a man has done a very few of these operations under supervision and with a little help from us he can be trusted to get first-rate results in 95 per cent. of the cases.

Srinagar.

\title{
AN INVESTIGATION INTO
}

\section{THE EFFECTS OF DRINKING-WATER} UPON THE CAUSATION OF DENTAL CARIES IN SCHOOL CHILDREN.

By J. BASIL COOK, M.D., B.S. VICT., D.P.H. CANTAB., M.R.C.S. ENG., L.R.C.P. LOND.,

MEDICAL SUPERINTENDENT TO THE BRENTFORD UNION INFIRMARY, ISLEWORTH.

THE widespread prevalence of dental caries among school children is a matter demanding the most serious attention of all who are responsible for, or interested in, the maintenance of the health and physique of the rising generation. The evils resulting from neglected defective teeth are well known, and the skilled dental attention associated with the systematic inspection of school children cannot be too highly appreciated. But prevention is better than cure, and no prophylactic measures on an extensive or national scale are possible while our knowledge of the primary causes of this con. dition remains in such a nebulous state.

A number of casual and disconnected observations in various parts of the country suggested to me the possibility of there being an association between the nature of the water used for drinking purposes and the prevalence of dental caries amongst the children. In the hope of obtaining information upon this subject the following schedule was printed on postcards, and a copy was sent to each of the school medical officers in the urban districts of England and Wales, together with a covering note explaining the nature of the investigation and a request for an early reply.

\section{BOROUGH OF}

YEAR, 1910.

Number of School Children over 12 years of age medically examined.

Number of School Children over 12 years of age having Foun or more carious teeth.......

\section{W ATER.}

Total Hardness =

Permanent ,"

Temporary ,"
$=$

$=$ parts per 100,000

",,$"$

ANY FURTHER INFORMATION CONCERNING

$A$. Water Supply-its nature, geological formation from which it is obtained.

$B$. Teeth of the children, prevalence of rickets, tubercle, \&c.

The inquiry was limited to children over 12 years. of age in order to avoid any confusion arising from the presence of defective teeth of the first dentition. Four or more carious teeth was the standard selected because it coincided with the returns. required by the medical officer to the Board of Education. No cards were sent to the school medical officers of rural districts because it was realised that the variations in the water-supplies, together with the small number of children in such localities, presented an insuperable obstacle to the collection of useful data. In all, 150 inquiries were sent out and about 100 answers were received. Owing to various reasons (such as the age-period quoted, or the number of teeth reported upon, differing from the schedule on the post-card; or the data. concerning the water-supply being omitted) the returns from 80 districts only were ultimately available for the purpose of correlating the nature of the water-supply with the amount of dental caries. And for similar reasons this number was still further reduced when dealing with the temporary 
and permanent hardness. The total hardness, the temporary hardness, and the permanent hardness were each in turn correlated with the percentage of children having four or more carious teeth. On account of the shortness of the series no correlation tables were used, but the product-moments were obtained by deviation from the mean for each individual case. The results are shown in Table A.

TABLE A.

\begin{tabular}{|c|c|c|c|c|}
\hline Variates, & $\begin{array}{c}\text { Number of } \\
\text { observa- } \\
\text { tions. }\end{array}$ & $\begin{array}{l}\text { Correla- } \\
\text { tions. }\end{array}$ & $\begin{array}{c}\text { Probable } \\
\text { error. }\end{array}$ & Remarks. \\
\hline $\begin{array}{l}\text { Total hardness of } \\
\text { water and percentage } \\
\text { of children with } 4 \text { or } \\
\text { more carious teeth. }\end{array}$ & 80 & 0.4702 & \pm 0.05 & $\begin{array}{l}\text { The harder } \\
\text { the water the } \\
\text { better the } \\
\text { teeth. }\end{array}$ \\
\hline $\begin{array}{l}\text { Temporary hardness } \\
\text { of water, and per- } \\
\text { centage of children } \\
\text { with } 4 \text { or more cari- } \\
\text { ous teeth. }\end{array}$ & 70 & 0.491 & \pm 0.06 & $\begin{array}{l}\text { The harder } \\
\text { the water the } \\
\text { better the } \\
\text { teeth. }\end{array}$ \\
\hline $\begin{array}{l}\text { Permanent hardness } \\
\text { of water, and per- } \\
\text { centage of children } \\
\text { with } 4 \text { or more cari- } \\
\text { ous teeth. }\end{array}$ & 73 & 0.303 & \pm 0.06 & $\begin{array}{l}\text { The harder } \\
\text { the water the } \\
\text { better the } \\
\text { teeth. }\end{array}$ \\
\hline
\end{tabular}

These correlations indicate that in the areas under consideration there is a definite association between the quality of the drinking-water and the amount of dental caries amongst the school children; the harder the water the better the teeth, and obversely. The slightly higher correlation in the case of the temporary hardness is of interest in view of the recently advanced hypothesis concerning calcium metabolism and dental caries. H. Ewan Waller, in the course of a most interesting article on "The Internal Secretions as the First Links in the Chain of Dental Caries," 1 points out that there is -

"some factor which makes the teeth more liable to decay during the period of growth than subsequently. ...... Some factor which confers considerable immunity against caries upon the victims of gout. ...... I think this elusive factor may be summed up in two words, calcium metabolism. ...... There is a heavy drain on the calcium content of the blood during the period of growth, the calcium, of course, being utilised to make bone. ..... Gout is essentially a disease of deficient metabolism, and the calcium elimination is slow. This is illustrated by the well-known ill-effect that hard waters have upon the victims of gout. ...... Where there is a special demand made as for skeletal growth ...... the shortage (of calcium salts) immediately becomes evident, and the saliva becomes defective in alkalinity and caries is liable to occur. There is probably a certain amount of truth in this supposition, and it is supported by the fact that a somewhat lower percentage of caries was found in the teeth of the children dwelling in the hard-water districts of Baden and Thuringia than in the children who lived only a few miles away but drank soft water."

The correlations in Table A certainly lend support to the foregoing hypothesis, but there are other important factors to be taken into consideration. Districts with a plentiful supply of soft water (especially if they be near a coalfield) are ipso facto peculiarly suited for the requirements of many manufacturing processes, and thus often have a more industrial population than localities having a harder water-supply. It is well known that in industrial districts the environment is unfavourable for the healthy upbringing of young children, and it is also generally accepted that the health and nutrition of a child during the first few years of its life have an important bearing upon the nature of its permanent teeth-weakly, underfed, and badly nourished children having, as a rule, worse per manent teeth than those reared under more favourable circumstances. It therefore follows that if some factor indicative of the well-being of the children in the localities under consideration could be obtained, and correlated with the figures giving the nature of the water-supply, the results might be expected to show some indication of the influences detrimental to the health in early life of the children in industrial populations.

In order to test this view the infantile mortality for the several districts was taken as an index to the physique of the children. The infantile mortality figures were obtained from the RegistraxGeneral's annual returns, and were correlated with the figures giving the respective hardness of the water-supply. Unfortunately, owing to the differences between the populations of the registration districts used by the Registrar-General, and the urban areas used by the Sanitary Authorities, many of the localities were unfitted for comparison. In all, the returns for 72 districts were found to be strictly comparable, and these were correlated with the following results:-

TABLE B.

\begin{tabular}{|c|c|c|c|c}
\hline Variates. & $\begin{array}{c}\text { Number of } \\
\text { observa- } \\
\text { tions. }\end{array}$ & $\begin{array}{c}\text { Correla- } \\
\text { tion. }\end{array}$ & $\begin{array}{c}\text { Probable } \\
\text { error. }\end{array}$ & Remarks. \\
\hline $\begin{array}{c}\text { Total hardness of } \\
\text { water and infantile } \\
\text { mortality. }\end{array}$ & 72 & 0.4133 & \pm 0.06 & $\begin{array}{c}\text { The harder } \\
\text { the water the } \\
\text { lower the } \\
\text { infantile } \\
\text { mortality }\end{array}$ \\
\hline
\end{tabular}

This correlation may be regarded as indicating a certain association, in the districts concerned, between the nature of the water-supply and those conditions (whatever they may be) which are conducive to a high death-rate amongst the infants in the population. It will be noted that this correlation, $0.4133 \pm 0.06$, is very similar to the correlation between the total hardness of the water and the number of children having four or more carious teeth-viz., 0.4702 \pm 0.05 . In other words, it may be assumed that in these localities the relation between the nature of the water"supply and the amount of dental caries is of a similar intensity to that between the nature of the watersupply and the infantile mortality.

The next step was to ascertain whether there is any association between the amount of infantile mortality and the amount of dental caries in the same districts. The figures for these two variates were therefore correlated as follows:-

TABLE C.

\begin{tabular}{l|c|c|c|c}
\hline Variates. & $\begin{array}{c}\text { Number of } \\
\text { observa- } \\
\text { tions. }\end{array}$ & $\begin{array}{c}\text { Correla- } \\
\text { tion. }\end{array}$ & $\begin{array}{c}\text { Probable } \\
\text { error. }\end{array}$ & Remarks. \\
\hline $\begin{array}{c}\text { Infantile mortality and } \\
\text { percentage of children } \\
\text { with 4 or more carious } \\
\text { teeth. }\end{array}$ & 72 & 0.4633 & \pm 0.06 & $\begin{array}{c}\text { The lower the } \\
\text { infantile } \\
\text { mortality the } \\
\text { better the } \\
\text { teeth. }\end{array}$ \\
\hline
\end{tabular}

It will be seen that here again there is an association rather stronger than that between the nature of the water-supply and the amount of infantile mortality, and approximating more closely to that between the nature of the water-supply and the amount of dental caries. But more information can be obtained from the foregoing data. It is obvious that several possible causes are operating, 
all at the same time, in producing variations in the amount of dental caries in the school children. The method of "partial correlation" enables us to measure the extent of relationship between two varying phenomena, when other interacting phenomena are kept constant throughout the series of observations. Thus, it is possible by means of a partial correlation to estimate the relation between the nature of the water-supply and the amount of dental caries for a constant infantile mortality. This has been worked out, and, taking infantile mortality as a measure of environmental conditions, the partial correlation is $0^{\circ} 3454 \pm 0^{\circ} 066$, indicating that the harder the water the better the teeth.

As it was not practicable to obtain for the districts under consideration the death-rates of children of the same age as those whose teeth were examined, another indirect index of the physique of the children was taken-namely, the general death-rate. This was correlated in turn with the total hardness of water and with the percentages of children having four or more carious teeth, the results being given in Table $D$.

\section{TABLE D.}

\begin{tabular}{c|c|c|c|c}
\hline Variates. & $\begin{array}{c}\text { Number of } \\
\text { observa- } \\
\text { tions. }\end{array}$ & $\begin{array}{c}\text { Correla- } \\
\text { tions. }\end{array}$ & $\begin{array}{c}\text { Probable } \\
\text { error. }\end{array}$ & Remarks. \\
\hline $\begin{array}{c}\text { General death-rate and } \\
\text { total hardness of } \\
\text { water. }\end{array}$ & 72 & 0.2965 & \pm 0.06 & $\begin{array}{c}\text { The lower } \\
\text { the general } \\
\text { death-rate } \\
\text { the harder } \\
\text { the water. } \\
\text { The lower } \\
\text { the general } \\
\text { death-rate } \\
\text { the better } \\
\text { the teeth. }\end{array}$ \\
$\begin{array}{c}\text { General death-rate and } \\
\text { percentage of children } \\
\text { having 4 or more } \\
\text { carious teeth. }\end{array}$ & 72 & 0.3178 & \pm 0.06 &
\end{tabular}

Here again there is an apparent, though less marked, association between the nature of the water-supply, the amount of dental caries, and the general death-rate. In a manner similar to the former, the relation between the nature of the water-supply and the amount of dental caries can be worked out for a constant general death-rate. In this case, taking the general death-rate as a measure of environmental conditions, the partial correlation is $0^{\circ} 4152 \pm 0^{\circ} 066$, indicating that the harder the water the better the teeth. This result, again, suggests an association between the nature of the water-supply and the condition of the teeth, hard water going with good teeth and vice ver's $t$.

The returns for the Yorkshire and Lancashire towns were next separated from those for the rest of England and Wales, and the figures for the nature of the water-supply and the amount of dental caries for the two groups were correlated separately. The results are given in Table E :-

\section{TABLE E.}

\begin{tabular}{c|c|c|c|c|}
\hline Variates. & $\begin{array}{c}\text { Number of } \\
\text { observa- } \\
\text { tions. }\end{array}$ & $\begin{array}{c}\text { Correla- } \\
\text { tions. }\end{array}$ & $\begin{array}{c}\text { Probable } \\
\text { error. }\end{array}$ & Remarks. \\
\hline $\begin{array}{c}\text { Total hardness of water } \\
\text { and the percentage of } \\
\text { school children with } \\
\text { four or more carious } \\
\text { teeth, Lancashire and }\end{array}$ & 23 & 0427 & \pm 0.11 & $\begin{array}{c}\text { The harcler } \\
\text { the water the } \\
\text { better the } \\
\text { teeth. }\end{array}$ \\
$\begin{array}{c}\text { Yorkshire towns only. } \\
\text { Total har inessof water } \\
\text { and the percentage of } \\
\text { school children with } \\
\text { four or more carious } \\
\text { teeth, rest of England } \\
\text { and Wales. }\end{array}$ & 56 & 0.408 & \pm 0.08 & $\begin{array}{c}\text { The harder } \\
\text { the water the } \\
\text { better the } \\
\text { teeth. }\end{array}$ \\
\hline
\end{tabular}

So far as these figures go they agree with the results given in Table $A$ and indicate that, assuming the social conditions in the industrial districts of Yorkshire and Lancashire to be less favourable for young children than in the rest of England and Wales, there is no evidence to show that such unfavourable surroundings have any influence upon the relationship between the hardness of water and the amount of dental caries amongst the school children.

It is well known that where people are crowded together certain unfavourable conditions are produced which injuriously affect the health of infants and young children. The consequences and concomitants of such aggregation produce the high infantile mortality of our manufacturing towns and other thickly populated areas. As another indirect measure of the social conditions in the districts under consideration the figures relating to over. crowding were taken from the General Census Report, and, in turn, correlated with the hardness of water and the percentage of carious teeth in each of the areas. The results are given in Table F :-

TABLe F.

\begin{tabular}{c|c|c|c}
\hline Variates. & $\begin{array}{c}\text { Number of } \\
\text { observations. }\end{array}$ & $\begin{array}{c}\text { Correla- } \\
\text { tions. }\end{array}$ & Remarks. \\
\hline $\begin{array}{l}\text { Number of persons per } \\
\text { house, and the total } \\
\text { hardness of the water. }\end{array}$ & 79 & 0.0526 & $\begin{array}{c}\text { Not } \\
\text { significant. }\end{array}$ \\
$\begin{array}{l}\text { Number of persons per } \\
\text { house, and the percent- } \\
\text { age of children having } \\
\text { four or more carious } \\
\text { teeth. }\end{array}$ & 79 & 0.0672 & $\begin{array}{c}\text { Not } \\
\text { significant. }\end{array}$ \\
\hline
\end{tabular}

It will be noted that in this table the correla. tions are calculated from 79 observations only. This is due to the fact that Aldershot, with its excessive aggregation of soldiers per house, so vitiated the value of the figures that it was omitted. There appears to be no association betreen the number of persons per house and the hardness of water or between the number of persons per house and the percentage of dental caries.

The partial correlation was next worked out for the relation between the hardness of water and the percentage of dental caries for a constant amount of overcrowding, Aldershot being excluded. In this case, taking a constant amount of overcrowding as a measure of environmental conditions, the partial correlation is $0.4643 \pm 0.059$; the harder the water the better the teeth. This result is noteworthy on account of its close approximation to the correlation between hardness of water and percentage of dental caries given in Table A. An attempt was also made to work out correlations in respect of rickets amongst the school children, but owing to paucity of data the results were not significant.

Conclusions.-1. The foregoing correlations and partial correlations indicate an association between excessive softness of water and an increased amount of dental caries amongst the school children, and obversely. 2. The association is evident, but it must be remembered that this inquiry deals only with urban districts; had it been possible to obtain reliable returns from rural districts its ralue would have been considerably enhanced. 3. The environmental conditions, so far as it was possible to measure them, do not seem to be a source of the relation between the hardness of water and the amount of dental caries. 4. It must be definitely and distinctly emphasised that these correlations and partial correlations merely call attention to an association between the nature of the drinking water and the amount of 
dental caries, and must not be regarded as necessarily indicating cause and effect. 5. There may well be other factors at work which have a greater influence, but if this investigation merely draws attention to a hitherto neglected topic it will not have been undertaken in vain.

Isleworth.

\section{A CASE OF MALARIAL COMA LASTING 46 HOURS : RECOVERY.}

BY A. G. TRESIDDER, M.D., B.S. LOND., CAPTAIN, INDIAN MEDICAL SERVICE.

THE following case is perhaps worthy of publication in the columns of THE LANCE'T, since recovery in a case of such long duration is exceptional, especially in an adult patient.

A. B., aged 23, a gunner serving in the Punjab, was admitted to hospital under my care on Nov. 29th, 1913. He was transferred from camp by Captain A. G. Jones, R.A.M.C., who informed me that the illness began whilst on manceuvres. He had been suffering from fever about three weeks previously, for which he was treated in hospital. He recovered from this and proceeded on mancurres, during which time he was receiving quinine daily. Early in the morning of the 29th, however, his comrades found him lying in his tent quite unconscious.

When I first saw the patient he had been unconscious for four and a half hours. On examination he was found to be in a condition of coma, with pupils widely dilated but which reacted directly and consensually to light. There were no signs of ocular paresis. The knee-jerks and plantar reflexes were both normal. All the limbs were stiff and rigid. His breathing was stertorous. The temperature was $102^{\circ} \mathrm{F}$; the pulse was regular and full, and its rate 104 per minute. There was incontinence of urine and no specimen was available for examination. There was no evidence of any injury to the skull and no localising symptoms of cerebral hremorrhage, and there was no smell of alcohol. The heart was normal, as also were the lungs. Captain J. W. H. Babington, I.M.S., reported that the fundi oculorum were quite normal except for slight venous dilatation and the presence of some fine dark pigment on the surface of both discs. A blood slide taken immediately on admission showed no malarial parasites, but with the history of ferer before the onset of coma the case was considered to be one of malignant malaria. An intramuscular injection of 10 grains of quinine hydrochloride was given at once, and this was followed after an interval of one hour by 5 grains of the same drug in a pint of normal saline vic the median basilic vein. Later calomel and pulv. jalapæ co. were given by the mouth. During the day the patient sweated freely, and he was sponged several times. Ten hours after admission a second intramuscular injection of 10 grains of quinine hydrochloride was administered.

Nor. 30th.-A slight improvement was evident. The pupils were less widely dilated and reacted well to light, and instead of the eyelids being open and the eyes staring straight above the patient the former were closed and any attempt to open them was resisted. There was still incontinence of urine, and as the bowels had not acted an enema of soap and water was given, but this was retained. At 2.30 P.M. a convulsion occurred; when I saw the patient shortly afterwards he was very cyanosed, his pulse was quick, and his breathing rapid and stertorous. A hypodermic injection of strychnine was given and a pint of normal salt solution administered per rectum. After 30 minutes the colour improved and the breathing became less stertorous. During the afternoon and erening the patient had seven more convulsive seizures; his condition was now very serious and there appeared to be little hope of recovery. These convulsions involved the whole body and they closely resembled the clonic stage of epilepsy. The tongue was bitten during the fits. Later the bowels were well opened, and a small quantity of urine which was secured showed the presence of a trace of albumin. At 10.30 P.M. the breathing was easy and regular; the pupils

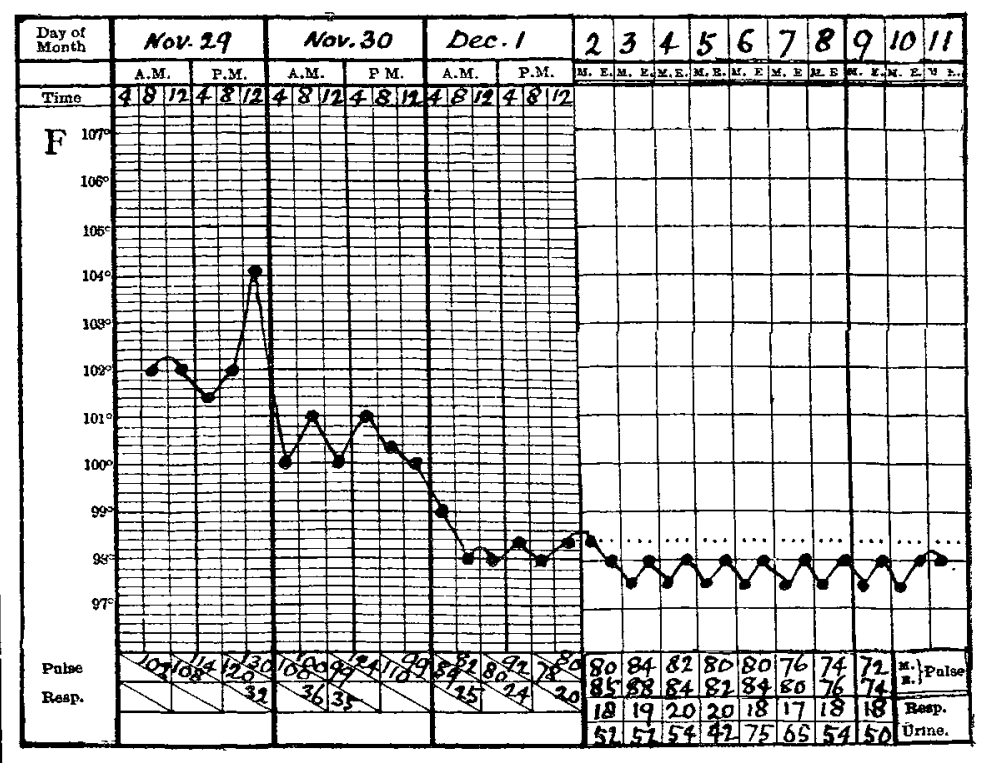

Temperature chart.

were contracted to $3 \mathrm{~mm}$. and reacted well to light. Two intramuscular injections of 10 grains of quinine were given during the day, and a total of three pints of saline given per rectum was retained.

Dec. 1st.-The rectal salines were continued every three hours during the night. At 2 A.r. some confused sentences were uttered, and two hours later he asked quite sensibly for a drink. At 9 A.m. he was able in a semi-dazed manner to reply to my questions. The pupils were normal, as was also the temperature. The pulse-rate was 88 per minute. 10-grain quinine injections twice a day and the salines per rectum were continued. Urine examination: Cloudy yellow colour; specific gravity 1016; acid reaction, albumin 1/10, no sugar. Microscopic examination of a brownish deposit showed the presence of urates only; there were no casts and no blood cells.

Dec. 2nd.-The patient was now able to take fluid nourishment, and the salines were therefore discontinued. The urine was as previously noted except that the amount of albumin was less. The patient became very restless; he was continually trying to remove the dressings from his arm, and he had to be forcibly restrained from getting out of bed. He also manifested marked delusions of persecution. Potassium bromide 20 grains and chloral hydrate 10 grains, followed by a subcutaneous injection of $\frac{1}{4}$ grain morphia, were unsuccessful in producing sleep. One injection, 10 grains, of quinine was given.

Dec. 3rd.-The patient's mental condition remained the same, and he suspected that his food was being poisoned. A potassium bromide and tincture of hyoscyamus mixture was given fourhourly during the day, and at night 1/100 grain of 